九州大学学術情報リポジトリ

Kyushu University Institutional Repository

\title{
A Study on the Relationship between Cooking Properties of Adzuki Bean and Storage Conditions
}

Hayakawa, Isao

Food Process Engineering Laboratory, Faculty of Agriculture, Kyushu University

Breene, William M.

Food Process Engineering Laboratory, Faculty of Agriculture, Kyushu University

https://doi.org/10.5109/23761

出版情報：九州大学大学院農学研究院紀要. 27 (1/2)，pp. 83-88，1982-10. Kyushu University バージョン：

権利関係 : 


\title{
A Study on the Relationship between Cooking Properties of Adzuki Bean and Storage Conditions
}

\author{
Isao Hayakawa and William M. Breene* \\ Food Process Engineering Laboratory, Faculty of Agriculture, \\ Kyushu University 46-09, Pukuoka 812 \\ (Received June 21,1982)
}

\begin{abstract}
Adzuki bean (Phaseolusangularis) has been used for many cooking purposes in Japan. The basic method for adzuki bean cooking is heating in the presence of moisture, it seems that the differences of moisture content between the beans before cooking and between cooking methods have influence on the qualities of cooking products. But there is a general complaint about the poor cooking properties of these beans. Since the cooking properties depend, both on the moisture contents of bean before cooking and the cooking method. This investigation deals with the effect of storage conditions like relative humidity and temperature in the container, on the $\alpha$-degree of starch, hydroscopic ratio and number of uncooked beans left after cooking. Results showed that water absorption of adzuki bean by soaking was very slow and took long time until saturation, temperature of water also influenced the absorption, and it was minimum at $5^{\circ} \mathrm{C}$. One year stored beans showed the lowest absorption, skin at the germ part changed due to over drying during storage, the low water absorption and decrease of hydroscopic ratio resulting in the poor cooking properties of the bean. But starch of the bean could not change easily on the quality of paste. Numbers of uncooked beans, when prolonged stored beans were cooked, could be decreased by pressure cooking $\left(2 \mathrm{kp} / \mathrm{cm}^{2}\right)$.
\end{abstract}

\section{N T R O D U C T I O N}

"An" (adzuki bean paste) is one of the typical traditional food in Far East countries, which is extensively being used in Japanese confectionaries for more than thousand years (Takei, 1969; Hatai, 1974, 1978). Recently, about $30 \%$ of total "An" production is used in ice-cream industry in Japan and Korea. Generally "An" is prepared from adzuki bean (Phaseohs angularis), cowpea (Vigna sinensis) and kidney bean (Phaseohs vulgaris), but "An" prepared from adzuki bean is of the best quality as for aroma, color and taste are concerned.

Adzuki bean plant can not withstand frost, but high quality of adzuki bean can grow in the moderate zone (accumulated temperature about $1,000-\mathrm{L} 100^{\circ} \mathrm{C}$ ) (Nippon Mamerui Kikin Kyokai, 1974). At present, most of the adzuki bean are produced in moderate zone, which have better skin quality and aroma as compared with the "bean" produced in tropical region. Skin of the adzuki

* Present address: Department of Food Science and Nutrition, University of Minnesota, 1334 Eckles Ave., St. Paul, Mn. 55108, USA. 
bean on near germ portion of seed differs from other kinds of beans in hydoscopic properties.' Since water imbibing on thk skin occurs only at germ, this characteristic effects the cooking quality of adzuki bean during storage. This study is to investigate the changes of cooking properties during the storage due to the change of high hydroscopic ratio and the seed size.

\section{MATERIALS AND METHODS}

Samples of Takara variety adzuki bean (Phaseolus angularis) grew in Minnesota (USA) and Hokkaido (Japan) in 1978 were collected, the beans were stored in different conditions, i. e., silo, storage room, living room (temperature : $20-22^{\circ} \mathrm{C}$ ) and no air control room in the farm. Samples (A-H) in Fig. 2 used are fresh. Samples which are stored under the given storage conditions were examined for the hydroscopic ratio, moisture contents and $\alpha$-degree of cooking properties were also measured according to the procedures described below.

1) Hydroscopic ratio was an increased ratio of weight per 100 grams of adzuki bean after soaking water for a fixed period of time. Moisture contents of adzuki bean was estimated at $105^{\circ} \mathrm{C}$ for $24 \mathrm{hr}$ in a dryer.

2) $\alpha$-degree of starch (ratio of gelatinization) of cooked bean was estimated by enzymatic method (Iwao, 1969). Cooking properties were examined by checking cooked adzuki bean condition in a steam pan. Chemical reagents were obtained from SIGMA Chemical Company (St. Louis, Mo. 63178, USA).

3) Humidity in a storage container was controlled by using saturated solution (Martin, 1962; Wexler and Brombacher, 1951; Wexler and Hasegawa, 1954). The following values were selected from the literatures interpolated to the temperatures mentioned against them : Lithium chloride $-12.4 \%\left(20^{\circ} \mathrm{C}\right)$, magnesium chloride $33.6 \%\left(20^{\circ} \mathrm{C}\right)$, potassium carbonate $-44.0 \%\left(20^{\circ} \mathrm{C}\right)$. potassium nitrite $-49.0 \%\left(20^{\circ} \mathrm{C}\right)$, magnesium nitrate $-54.9 \%\left(20^{\circ} \mathrm{C}\right)$, sodium nitrite $-65.3 \%\left(20^{\circ} \mathrm{C}\right)$. ammonium sulfate $-80.6 \%\left(20^{\circ} \mathrm{C}\right)$, potassium nitrate $-93.2 \%$ $\left(20^{\circ} \mathrm{C}\right)$, potassium bichromate $-98.2 \%\left(20^{\circ} \mathrm{C}\right)$.

\section{RESULTS AND DISCUSSION}

\section{Physical properties and analytical data}

Adzuki beans differ from soy bean due to higher carbohydrate contents (more than $50 \%$ on dry basis), and they also contain about 20-28\% crude protein, therefore that is grouped into protein riches. Analytical and physical properties of adzuki beans are shown in Table 1 . The thousand kernels weight of Japanese adzuki bean ranged between $100-120 \mathrm{~g}$, whereas, Minnesota beans are a bit bigger in size and weighed around $150 \mathrm{~g}$, resembling with "Japanese Dainagon", and also fetch higher price.

\section{Relationship between hydroscopic ratio and soaking time}

Hydroscopic ratio (\%) of adzuki bean is very poor as shown in Fig. 1. Especially the hydroscopic ratio just after soaking in cold water is very low and there is sharp increase in hydroscopic ratio after $10 \mathrm{hr}$ of soaking. Log. 
Table 1. Analytical data and physical data of adzuki bean.

Carbohydrate
Crude protein*)
Ash
Lipid
Fiber
Moisture
Volumetrical weight
Weight of 1.000 seeds
D e $n$ s $\mathrm{y}$
Ratio between skin and end
lfuric method.
$\mathrm{N}$ x 6.25 .
rm-methanol mixture $(1: 1)$.
ao (1969).

1) Phenol-sulfuric method

2) Kjeldahl $\mathrm{N} \times 6.25$.

3) Chloroform-methanol mixture (1:1).

4) From Iwao (1969).

arithmic curved line usually is seen as special about adzuki beans. Whereas, while soaking in warm water hydroscopic rate increases. After six months of storage, hydroscopic ratio of adzuki bean decreased about $1 / 8$ of the fresh beans.

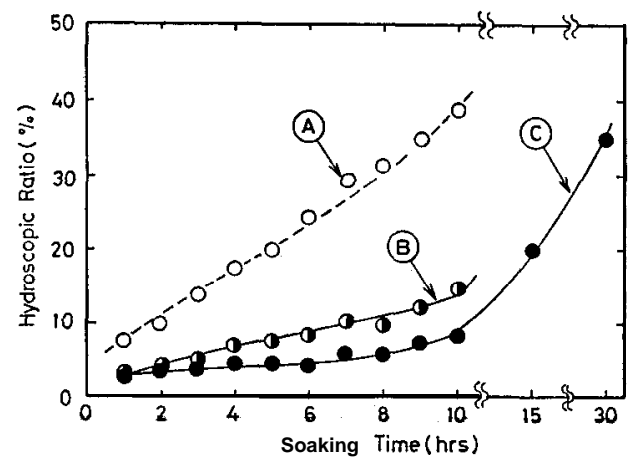

Fig. 1. Relationship between soaking time and hydroscopic ratio on different soaking temperature as follows: $\mathrm{A}=20^{\circ} \mathrm{C}$ (fresh bean), B: $5^{\circ} \mathrm{C}$ (fresh bean), $\mathrm{C}=20^{\circ} \mathrm{C}$ (bean stored for 7 months). ties

Relationship between water contents, hydroscopic ratio, and cooking proper-

Water contents and hydroscopic ratio affected the cooking properties of adzuki bean to a large extent. Samples under different storage conditions are shown that cooking properties were highly correlated with hydroscopic ratio and water contents of adzuki bean. The bean with high moisture contents and high hydroscopic ratio showed better cooking properties (Fig. 2).

Relationship between relative humidity and moisture contents of adzuki bean during storage

Relative humidity during storage period had direct bearing on the moisture contents as shown in Fig. 3. Changes on the skin surface could be easily 


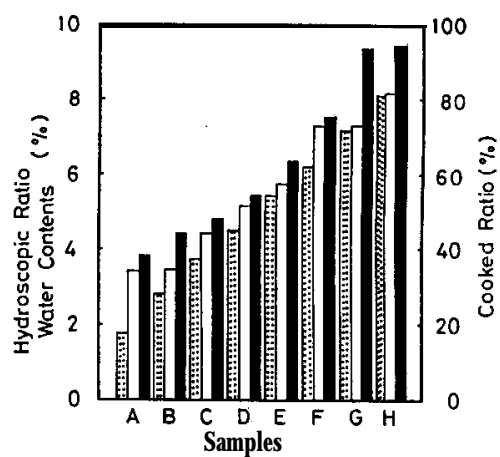

Fig. 2. Relationships among hydroscopic ratio, water contents and cooking properties on adzuki bean which were stored under different conditions. Everything was stored for three months at $20^{\circ} \mathrm{C}$, relative humidity in the storage container was adjusted as follows: $\mathbf{A}=12.4 \%, \mathbf{B}=33,6 \%, \mathbf{C}=\mathbf{4 4 . 0}$ $\%, \mathrm{D}=54.9 \%, \mathrm{E}=65.3 \%, \mathrm{~F}=80.6 \%$ and $\mathbf{G}=98.2 \%, \mathbf{H}$ is fresh beans. Dotted column: water contents, blank column : hydroscopic ratio, solid column: cooked ratio of adzuki bean.

detected after two weeks of storage, and little mold growth was observed after three weeks of storage under high humidity condition, whereas, a decrease in moisture contents was observed under low humidity storage. The storage test showed adzuki beans which were stored under dry conditions ("A" and "B") remained partially uncooked even after 90 min of cooking. Results showed that if moisture contents of adzuki bean during storage fall below $8 \%$, cooking properties were adversely affected.

A silo storage test under similar conditions as the farmers in Minnesota are actually used for storage of other grains in the farm showed that beans did not have any prominent change after six months of storage in the silo. A little change in moisture contents was observed, whereas cooking properties

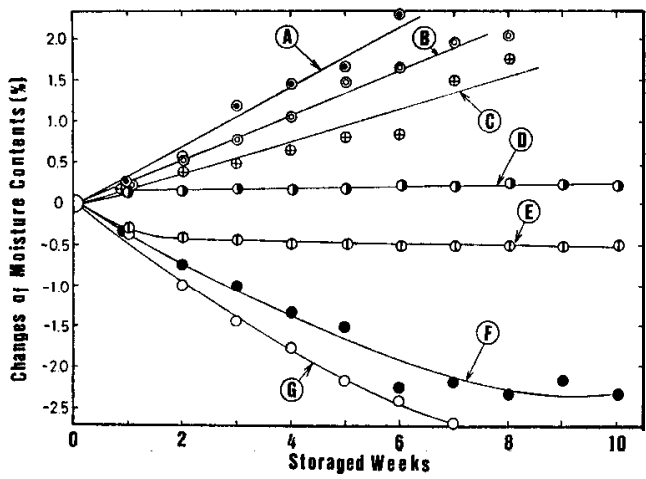

Fig. 3. Influences of relative humidity in storage container on water contents of stored adzuki bean. $\mathbf{A}=12.4 \%, \mathrm{~B}=33.6 \%, \mathrm{C}=44.0 \%, \mathrm{D}=\mathbf{5 4 . 9} \%$, $\mathbf{E}=65.3 \%, \mathbf{F}=\mathbf{8 0 . 6 \%}, \mathbf{G}=\mathbf{9 8 . 2} \%$. 
remained unaffected, which might be attributed to the extremely cold winter season.

\section{Influence of storage on cooking properties of adzuki bean}

Storage conditions of the bean greatly affected the cooking properties as shown in Fig. 4. Fresh beans showed about $50 \%$ starch $\alpha$-degree when gelatinized after $60 \mathrm{~min}$ boiling and around $75 \%$ after $90 \mathrm{~min}$ boiling. Whereas, the bean stored for more than one year showed only $18 \%$ starch $\alpha$-degree and it only up to $70 \%$ after excessive cooking. The deterioration of cooking properties of adzuki bean after storage may be mainly due to the reason that germ portion in the seed which is the main water imbibing spot become inactive storage resulting from excessive moisture loss from the skin after storage. The deterioration of cooking properties was as shown in Fig. 4. The above conclusion was verified when comparison between the fresh bean scratched after storage was conducted on the basis of their cooking properties.

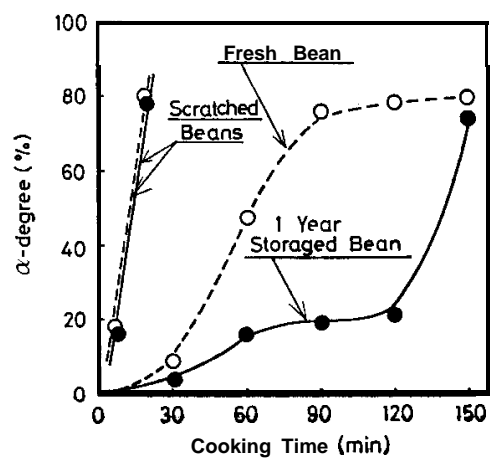

Fig. 4. Differences of cooking properties among fresh bean, one-year stored bean and scratched bean after being stored for one year.

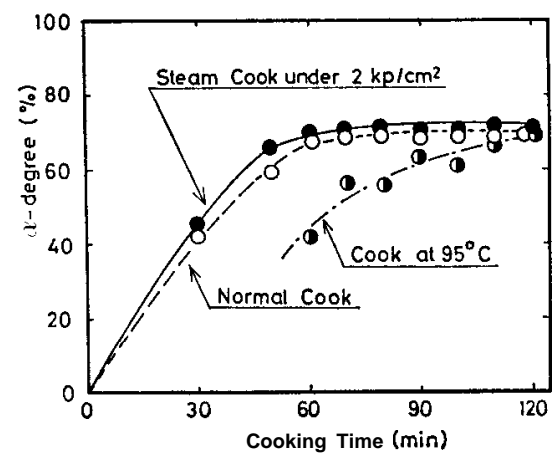

Fig. 5 Relationship between cooking time and a-degree of adzuki bean starch.

Results revealed that cooking properties after beans stored for one year were unaffected as the bean was scratched at germ before cooking, so it can 
be safely concluded that cooking properties were affected mainly due to the loss of water imbibing spot (germ) after storage, and this defect can easily be overcome by providing other imbibing spot on the skin, simply_ by scratching. If moisture percentage of the bean, during storage fell below $6 \%$, the bean germination and cooking properties would be affected. Relationship between cooking temperature and starch a-degree is represented in Fig. 5. Boiling under $2 \mathrm{kp}$ for $45 \mathrm{~min}$ gives $70 \%$ starch a-degree, which showed a 25 $\%$ cut in boiling time than that of normal cooking, whereas, cooking at $95^{\circ} \mathrm{C}$ prolonged boiling time to 120 min to get the same value of a-degree.

From the above results, fresh beans are the best materials for 'the preparation of "An" (adzuki bean paste), but there is no difference on cooking properties of which adzuki bean has been stored in the silo. Because atmospheric temperature is very cold after harvesting adzuki bean in Minnesota. Therefore adzuki bean has a high quality during all season in Minnesota.

\section{REFERENCES}

Hatai, A. 1972 Study on the cooking characters of adzuki bean. J. Hokkaido Univ. Educ., 24 (2) : 23-29,

Hatai, A. 1978 Relationship between processing of An paste and its quality. J. Chorikaguku, 11: $42-50$

Iwao, H. 1969 Denpun no teiryo. In "Shokuhin Bunseki Hand Book", ed. by Obara et al., Kenpakusha, Tokyo, pp. 246-249

Martin, S. 1962 The control of conditioning atmospheres in small sealed chambers. J. Sci. Instr., 39: 370-376

Nippon Mamerui Kikin Kyokai 1974 Mamerui no Atarashii Saibaiho. Miyoshi Insatsu, Tokyo, pp. 227-229

Takei, H. 1969 Nama an seizo gijutsu no shinpo. Food Industry, 12: 24-28

Wexler, A. and W. Brombacher 1951 Methods of measuring humidity and testing hydrometers. NBS Circular, no. 512

Wexler, A. and S. Hasegawa 1954 Relative humidity-temperature relationship of some saturated salt solution in the temperature range from 0 to $50^{\circ} \mathrm{C}$. J. Res. NBS, 53: $19-20$ 